\title{
Peertechz
}

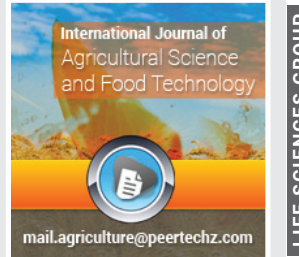

\section{Promotion of improved onion technology through FRG System in Fadis and Babile districts of East Haraghe Zone}

\author{
Abdulaziz Teha* \\ Oromia Agricultural Research Institute, Fedis Agricultural Research Center, P.O. Box 904, \\ Harar, Ethiopia
}

Received: 20 December, 2021

Accepted: 06 January, 2022

Published: 07 January, 2022

*Corresponding author: Abdulaziz Teha, Oromia Agricultural Research Institute, Fedis Agricultural Research Center, P.O. Box 904, Harar, Ethiopia,

E-mail: abdulaziztaha@gmail.com

Keywords: Demonstration; Red Bombay; FRG

Copyright License: @ 2022 Teha A. This is an openaccess article distributed under the terms of the Creative Commons Attribution License, which permits unrestricted use, distribution, and reproduction in any medium, provided the original author and source are credited.

https://www.peertechzpublications.com

\section{Abstract}

Pre extension demonstration of onion varieties was conducted at Fadis and Babile districts of East Hararghe zone one kebele from one FRG established and 10 trial farmers. Both varieties were sown on $10 * 10$ plot size of demonstration plots with full package technology. The training was given for farmers on onion agronomic practices to make full package technology. The bulb yield of the improved onion varieties (Red Bombay and local) were $22.86,18.74$ ton/ha at Erer and $22.00,17.92$ ton/ha Ballina Arba Kebele respectively. The result showed that there was a significant difference between both varieties at $<1 \%$ level. Red Bombay has a $22.37 \%$ yield advantage over local check.

\section{Introduction}

Onion ((Allium cepa $L)$ is an important vegetable crop, which has been produced worldwide including of Ethiopia for its daily uses and economic benefits [1]. The onion is recognized as one of the most important vegetable crops cultivated throughout the world since its introduction to the world [2]. It has grown mainly as a food source and used as cousins and value addition for different dishes. The chemical flavonoids, anthocyanins, fructo-oligosaccharides and organosulphur compounds found in the onion is considered as medicinal and health benefits to fight different diseases including cancer, heart and diabetic diseases [2]. The average annual onion production in Ethiopia is about $230,745.2$ tons with a productivity of about $9.5 \mathrm{t} \mathrm{ha}^{-1}$, which is very low compared to the potentials the country has (CSA) [3].

Despite its lower productivity, which brings below the world average, onion is becoming the source of livelihood for many peoples who have engaged in production and trading. The main reason for this lower productivity of the crop is most probably due to lack of improved onion, inappropriate agronomic practices and little-given attention to crop production [1].
However, the area under cultivation is increasing from time to time both under rain feed and irrigation conditions due to its economic profitability. Also, an inevitable yield and yield component improvement activities including plant nutrient management, crop water requirements and scheduling programs, plant population densities, and disease and insect pest control systems were identified [1].

The result of the Adaptation trial done by Fadis Agricultural Research Center showed that Melkam gave maximum bulb yield $294.64 \mathrm{qt} /$ ha which means double of the standard check (132.58qt/ha) followed by Bombay Red 224.55qt/ha and Nasik Red 206.69qt/ha, respectively. Thus, Melkam showed good field performance and attractive bulb size and bulb color. However, Nasik has good quality. The objective of this study is to promote Red Bombay and local Onion technology with full package in Babile and fadis. This project aimed at alleviating the problems of low quality Onion obtained from informal seed sectors and ensures the benefits to be obtained from improved Onion varieties [4-7].

\section{Specific objectives}

$\checkmark$ To promote full packaged improved onion technology. 
To increase the production of onion producer farmers in the study districts

$\checkmark$ To improve farmers' knowledge and skill of onion producer farmers in the study districts.

\section{Materials and methods}

\section{The description of the study of area}

Fedis district has the altitude range is from 1200-1600m.a.s.l meters, with a prevalence of low lands. The area receives average annual rainfall of $400-804 \mathrm{~mm}$. The mean monthly temperature of the area is $22.2^{\circ} \mathrm{C}$ and $32.5^{\circ} \mathrm{C}$, respectively. The farm units are small family holdings with an average agricultural land area of less than one hectare. Agriculture is mainly rain-fed.

Babile is located on distance of $31 \mathrm{kms}$ from Harar in the direction of county's Eastern part. It is bordered by Gursum in Northern, Fedis in south, sumale region in eastern, Harari region and Fedis in western and Jarso in Northwest district. Erer ibada and Ibada Gemechu are located on distance of $33 \mathrm{~km}$ from Harari region and Erer Ibada located at $09^{\circ} 10^{\prime} 41.5^{\prime}$ north of latitude, $042^{\circ} 15^{\prime} 27.3^{\prime}$ east of longitude and elevation $1274 \mathrm{~m}$ a.s.l. The climatic condition of this area is almost dry land. It has bimodal nature of rainfall. The socio-economic character of the population in the study area depends on subsistence agriculture.

\section{Site and farmers selection}

The activity was conducted in the selected district of East Hararghe Zone for the consecutive two years of the cropping season. Fadis and Babile district were selected based on the potentiality of onion Production and accessibility for close monitoring. Erere Ibada from Babile and Ballina Arba from Fadis district were selected purposively in collaboration with experts and development agents of the Office of Agriculture and Natural resource.

From each kebeles, one FRG (Farmer Research Group) member considering gender and youth consisting of 15 farmers were established and Farmers Research Group (FRG) with the member of 15 ( 3 male trial farmers and 2 female trial farmers) and 10 farmers work with trial farmers. Member of FRG farmers were selected based on; their interest on technology, willingness to cost sharing like land provision, labor work and willingness innovative experience sharing for the members as well as non-members of target farmers.

\section{Experimental design}

One improved treatments Onion (Red Bombay and local) variety, replication-replicate across five trial farmers per PAs. One improved and one local variety were sown on 10 farmers. $10 \mathrm{~m} * 10 \mathrm{~m}$ plot size used. Spacing $20 \mathrm{~cm}$ between rows and $10 \mathrm{~cm}$ between plants $(10 \mathrm{~cm} * 10 \mathrm{~cm})$ gives a higher yield. Fertilizer application rate $100 \mathrm{~kg}$ NPS and $150 \mathrm{~kg}$ Urea in split 30-45 days after planting is recommended and seed rate $4 \mathrm{~kg} / \mathrm{ha}$.

\section{Data collection}

Both quantitative and qualitative data were collected through personal field observation, individual interview by using checklist and datasheet. Quantitative data such as number of farmers who participated, yield performance, number of stakeholders who participated in training and field days were collected. Qualitative data such as farmers' feedback and perception toward the new technology were also collected.

\section{Data analysis}

Quantitative data was summarized using simple descriptive statistics (Mean, Frequency and Percentage), independent samples t-test. While the qualitative data collected using group discussion and key informant interviews, field observation and oral histories was analyzed using narrative explanation tools and argument. Finally, data from different sources was triangulated to get reliable information.

\section{Results and discussion}

\section{The promoted onion varieties bulb yield across the study site}

The bulb yield of the improved Red Bombay and local were variety 22.86, 18.74, 22.00 and 17.92 ton/ha at Ballina Arba and Erer Kebele respectively Table 1.

\section{Independent t-test}

Tables 2,3.

\section{Economic analysis}

Table 4.

\section{Knowledge test before and after the interventions}

Score of 1 is given for correct answers and o for incorrect answers. As one can observe from Table 5.

Table 1: The Onion bulb yield across the districts.

\begin{tabular}{|c|c|c|c|c|c|c|}
\hline PA & Varieties & No & Std. Deviation & $\begin{array}{c}\text { Mean (ton/ } \\
\text { ha) }\end{array}$ & Maximum & Minimum \\
\hline \multirow{2}{*}{ Erer } & Red Bombay & 5 & .66 & 22.86 & 23.40 & 21.70 \\
\cline { 2 - 8 } & Local & 5 & .68 & 18.74 & 19.70 & 17.90 \\
\hline \multirow{2}{*}{ Ballina } & Red Bombay & 5 & .44 & 22.00 & 22.60 & 21.50 \\
\hline Arba & Local & 5 & .63 & 17.92 & 18.70 & 17.10 \\
\hline \multicolumn{2}{|r|}{ Total } & 10 & 2.22 & 20.38 & 23.40 & 17.10 \\
\hline
\end{tabular}

The average bulb yield of Red Bombay is higher than local at Ballina arba and Erer

Table 2: Sample t-test.

\begin{tabular}{|l|c|c|c|c|c|c|c|}
\hline & $\begin{array}{c}\text { Test for equal } \\
\text { variances }\end{array}$ & \multicolumn{5}{|c|}{ t-test for equality of means } \\
\hline & $\mathrm{F}$ & Sig. & $\mathrm{T}$ & $\mathrm{df}$ & $\begin{array}{c}\text { Sig. } \\
(2 \text {-tailed) }\end{array}$ & $\begin{array}{c}\text { Mean } \\
\text { difference }\end{array}$ & $\begin{array}{c}\text { Std. Error } \\
\text { Differences }\end{array}$ \\
\hline $\begin{array}{c}\text { Equal variances } \\
\text { assumed }\end{array}$ & .05 & .81 & 12.53 & 18 & .00 & 4.10 & .32 \\
\hline
\end{tabular}

Table 3: Yield Advantage.

\begin{tabular}{l|l|l|l} 
Varieties & Average yield ton/ha & Yield difference ton/ha & Yield advantage (\%)
\end{tabular}

\begin{tabular}{|c|c|c|c|}
\hline Red Bombay & 22.43 & 4.1 & 22.37 \\
\hline Local & 18.33 & & \\
\hline
\end{tabular}


The mean score for knowledge test before intervention and after intervention is 5.3 and 6.4 respectively. The result of paired-sample $t$-test indicates a significant difference between the mean score for knowledge test before intervention and after intervention at $1 \%$ significant level. This implies an improvement of farmers' knowledge regarding the improved onion technologies due to technological intervention Table 6.

\section{Farmers' opinion/perception}

The farmers' criteria were early maturity, Yield, disease tolerance, leaf color, bulb size, bulb shape, bulb skin color and seed set Table 7 .

\begin{tabular}{|c|c|c|c|c|}
\hline \multirow{2}{*}{\begin{tabular}{c} 
Table 4: Financial analysis for Onion varieties across the districts. \\
\hline Parameters
\end{tabular}} & \multicolumn{2}{|c|}{ Babile(Erer) } & \multicolumn{2}{c|}{ Fedis (Ballina Arba) } \\
\hline Yield ton/ha(Y) & \multicolumn{2}{|c|}{ Varieties } & \multicolumn{2}{c|}{ Varieties } \\
\hline Red Bombay & Local & Red Bombay & Local \\
\hline Price(P) per quintal & 22.86 & 187.4 & 22.0 & 179.2 \\
\hline Total Revenue (TR)=TR=Y*P & 1500 & 1500 & 1500 & 1500 \\
\hline Variable costs & 342,900 & 281,100 & 330,000 & 268,800 \\
\hline Seed cost & 12,800 & 12,800 & 12,800 & 12,800 \\
\hline Fertilizer cost & 1,418 & 1,418 & 1,418 & 1,418 \\
\hline Labor cost & 35,000 & 35,000 & 35,000 & 35,000 \\
\hline Fuel Cost & 10,000 & 10,000 & 10,000 & 10,000 \\
\hline Total Variable costs(TVC) & 59,218 & 59,218 & 59,218 & 59,218 \\
\hline Fixed costs & & & & \\
\hline Cost of land & 8000 & 8000 & 8000 & 8000 \\
\hline Total Fixed Costs (TFC) & 8000 & 8000 & 8000 & 8000 \\
\hline Total Cost (TC) =TVC+TFC & 67,218 & 67,218 & 67,218 & 67,218 \\
\hline Gross Margin (GM) = TR - TVC & 283,682 & 221,882 & 270,782 & 209,582 \\
\hline Profit=GM-TFC & 275,682 & 213,882 & 262,782 & 201,582 \\
\hline
\end{tabular}

Table 5: Percentage of Respondents for each knowledge Items.

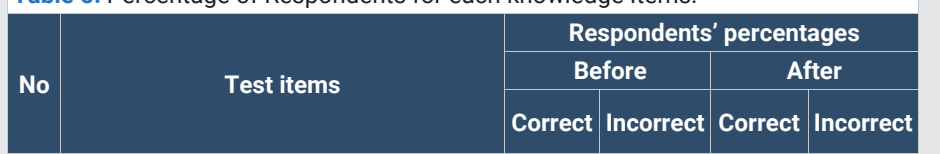

\begin{tabular}{|c|c|c|c|c|c|}
\hline 1 & $\begin{array}{l}\text { The Name of improved onion variety } \\
\text { used }\end{array}$ & 37 & 63 & 55.6 & 44.4 \\
\hline 2 & Ploughing frequency for onion & 48.1 & 51.9 & 59.3 & 40.7 \\
\hline 3 & $\begin{array}{c}\text { The recommended spacing of improved } \\
\text { onion }\end{array}$ & 44.4 & 55.6 & 48.1 & 51.9 \\
\hline 4 & Transplanting date of onion & 40.7 & 59.3 & 51.9 & 48.1 \\
\hline 5 & $\begin{array}{l}\text { The recommended seeding rate of } \\
\text { improved onion }\end{array}$ & 55.6 & 44.4 & 63 & 37 \\
\hline 6 & The Maturity date of onion & 33.3 & 66.7 & 40.7 & 59.3 \\
\hline 7 & $\begin{array}{c}\text { The symptom of disease that affect } \\
\text { onion }\end{array}$ & 51.9 & 48.1 & 51.9 & 48.1 \\
\hline 8 & The disease tolerant varieties & 40.7 & 59.3 & 44.4 & 55.6 \\
\hline 9 & $\begin{array}{l}\text { The chemical application frequency of } \\
\text { onion }\end{array}$ & 29.6 & 70.4 & 33.3 & 66.7 \\
\hline 10 & The chemical used for onion & 25.9 & 74.1 & 37 & 63 \\
\hline 11 & Yield per hectare of improved onion & 48.1 & 51.9 & 48.1 & 51.9 \\
\hline 12 & Market price of onion & 37 & 63 & 40.7 & 59.3 \\
\hline 13 & Exact Source of improved onion seed & 44.6 & 55.4 & 66.7 & 33.3 \\
\hline
\end{tabular}

Table 6: Paired-sample t-test.

\begin{tabular}{|c|c|c|c|}
\hline & Mean & St.Dev & t-value \\
\hline Total score before & 5.3 & 1.69 & 4.34 \\
\hline Total score After & 6.4 & 2.11 & \\
\hline
\end{tabular}

Significance difference at $1 \%$ level before and after the intervention of the technology

Source: Computed from own data (2021)

\begin{tabular}{|c|c|c|}
\hline \multicolumn{2}{|l}{ Table 7: Ranks of the varieties. } \\
\hline Varieties & $\begin{array}{c}\text { Farmers } \\
\text { rank }\end{array}$ & Reasons \\
\hline Red Bombay & $1^{\text {st }}$ & $\begin{array}{r}\text { Medium maturity, High Yield, diseases tolerance, Dark } \\
\text { green leaf color, medium bulb size, flat Glob bulb shape, } \\
\text { light red bulb skin color and seed set }\end{array}$ \\
\hline Local & $2^{\text {nd }}$ & $\begin{array}{r}\text { Medium maturity, Low yield, low diseases tolerance, green } \\
\text { leaf color, low bulb size, flat Glob bulb shape, red bulb skin } \\
\text { color and seed set }\end{array}$ \\
\hline
\end{tabular}

\section{Conclusion and recommendation}

Generally, the bulb yield of Red Bombay and local variety were 22.86 and 18.74 ton/ha at Erer, 22 and 17.92 ton/ha at Balina arba, respectively. The average yield performance of Bombay Red and local at both location was statistically significant difference at $1 \%$ across the location. The wider promotion of Red Bombay is recommended to reach more farmers and wider area. Based on its maturity, yield, diseases tolerance, Dark green leaf color, medium bulb size, flat Glob bulb shape, light red bulb skin color bombay red varieties was recommended for further scaling up.

\section{References}

1. Etana MB (2019) Major onion (Allim Cepa.L) Production challenges in Ethiopia:A Review. 9. Link: https://bit.ly/3oQyR50

2. Goldman IL (2011) Molecular breeding of healthy vegetables. EMBO Rep 12 96-102. Link: https://bit.ly/3nOwkEo

3. CSA (2014) Area and production of major crops. agricultural sample survey. Central Statistical Authority, Addis Ababa, Ethiopia. Link: https://bit.ly/3eXvQKE

4. CSA (2008) Report on area, production of crops (private peasant holdings meher season). Agricultural sample survey 2007/2008.V.I. Addis Ababa. Link: https://stanford.io/3G3cG1R

5. Harrun H, Nikus O, Mesfin T, Beshir B (2009) Participatory determination of plant density for optimum onion bulb yield production under irrigation. In Bedru Beshir et al (Eds.). Proceeding of FRG completed projects of collaborative project EIAR, ORARI and JICA on Strengthening technology development, verification, transfer and adoption through Farmers Research Group (FRG).

6. MoARD (2009) Crop Variety Registration ISSUE No.12. Addis Ababa, Ethiopia

7. Olani N, Mulugeta F (2010) Onion Seed Production Techniques. A Manual for Extension and seed Agents producers. FAO Crop Diversification and Marketing Development Project. Link: https://bit.ly/3eTFRIH 